\title{
Protection, Prosperity, Progress:
}

\section{A Stronger Euro for a Stronger Europe*}

\section{Jean-Claude Juncker}

It is a real honour indeed to be invited to give this year's Tommaso Padoa-Schioppa Lecture. I knew of Tommaso even before I met him in the late 1980s. I had read his speeches, studied his papers on Europe's economy dating back to when he was a Director-General at the Commission. Tommaso was never President of the Commission. In order to complete what he was saying as far as the Commission is concerned, I have to quote Jacques Delors. Jacques Delors said: the President of the Commission has no allies at all. That was true during his time; it is true today.

I am delighted that Marco Buti is honouring the long tradition of Italians in charge of economic affairs in the Commission by following in Tommaso's footsteps!

This tradition shows Italy's place is at the heart of Europe and of the euro. And it reflects how much this country has done to build a united Europe. Italy - yesterday as today - deserves respect and trust.

This also sums up my relationship with Tommaso - someone I was proud to call a friend. I got to know him well when he was rapporteur on the Delors Committee in the late 1980s and then spent countless hours with him day and night around the tables of the Eurogroup and ECOFIN.

His European heart, soul and conviction led him to dedicate his career and in fact his life to our Union and our single currency. Hislegacy lives on today. For him, as it is for me, the economy is always about people and values, rather than statistics and percentages. And for him, the euro was the most powerful symbol of what Europe is about. As he said in 1999: "our new currency unites not only economies, but also the people of Europe. This represents a profound change in human history."

Almost two decades on, these words are as true as ever. And as we look to the future, wemust never lose sight of what the Economic and Monetary Union is there to do: offer protection, prosperity and progress to Europeans.

Last Friday, we marked 20 years of the European Central Bank. And on the first of January next year, we will celebrate 20 years of our single currency.

It has come a long way in that time and it is a true European success story. Today, 340 million Europeans use the euro every day in 19 of our Member States. And the euro area will soon represent $85 \%$ of the overall gross domestic product of the entire European Union.

Across the world, the euro is now the second most used reserve currency, with 60 countries now linking their currencies to the euro in one way or another.Weshould never underestimate how far the euro has come.

But neither should we underestimate the existential crisis that we have been through. The global financial and economic crisis that started in the United States in 2007 and 2008 hit us hard.

It was by far the worst economic and social crisis in Europe since the Second World War. And it has left deep scars on our political, economic and social fabric, which we are still struggling to address.

This is why when I came into office, I said that we could not simply turn the page as if nothing happened. We could not go back to business as usual. We needed to learn our lessons and 
make a change. We needed a kind of new start for Europe.

This is why we made the return of jobs and growth our number one priority.

We launched the Investment Plan for Europe in former times it was called the Juncker Plan, when it was not sure it would be a success. Those who thought that it would be a total failure wanted to pre-identify the one who would be responsible for the failure. Now it works and it has become European fund for strategic investments, but it is exactly the same. We used the necessary flexibility within the rules of the Stability and Growth Pact.

We supported young people to get into work via an instrument which is known as the Youth Guarantee.

We strengthened our single market in all its forms - and you will discuss the importance of the digital economy throughout the day. The Digital Single Market in fact leads to an added value of EUR 415 billion per year, so it is not a minor dimension of what has to be done in the next coming years.

And we stood up for fair and free trade around the world, which is a source of jobs.

Together with tough decisions taken by Member States, and determined action by the European Central Bank, this has helped to make a difference. Economic growth within the euro area reached a 10-year high in 2017, surpassing the United States and Japan for the last two years. Almost 13 million jobs were created in the European Union since the height of the crisis in 2013. Almost 8 million of those new jobs were in the euro area. I am not claiming that the Commission created 8 million jobs, but if we had lost 8 million jobs I am sure that the Commission would have been held responsible.

As a result, employment is now at a record high, with 237 million people working across our Union. Unemployment is at its lowest level since 2008. And there are many other encouraging signs of improvement. Investment has finally picked up again. With the Plan, with the EFSI, we expect to have already triggered more than EUR 287 billion in investment, creating 300,000 jobs and supporting around 635,000 small businesses in the process. By 2020, the Plan is expected to help increase GDP by $0.7 \%$ and create 700,000 jobs. And we will build on this success story of using scarce public resources to mobilise even more private investments in our next multi-annual budget period.

Another significant improvement is that public finances are in a much healthier state. The public deficit in the euro area has decreased from over $6 \%$ in 2009 to as low as $0.7 \%$ in 2018 . I know that mainly in the northern part of the European Union some are saying that we did not respect the Stability and Growth Pact. But the result is there. By respecting the Stability and Growth Pact, by reading it in economic terms, we were able to decrease the public deficit to $0.7 \%$ in 2018.

Our levels of debt also continue to decrease. The ratio of government debt to the gross domestic product is forecast to fall to $86.5 \%$ this year in the euro area, down from $94.2 \%$ in 2014 .

But we know that all these improvements are not enough. We have challenges ahead of us and I see mainly two major ones.

The first is to make sure that our recovery benefits everyone. This means that we must address the root causes of social despair, which were exacerbated over the last decade. Some say this is a matter for national governments or for social partners alone. I say this is a matter for everyone in Europe. This is why we made it a priority to strengthen Europe's social dimension as much as its economic dimension. I think Tommaso would agree. I know that he would agree.

Like him, I believe in the social market economy. I believe in what the economy can do for people, rather than in what people can do for the economy. This is why I am particularly proud of the unanimous proclamation of the European 
Pillar of Social Rights by all leaders and institutions last November in Gothenburg. This Social Pillar is not just a poem or a declaration it is now a key part of the way we monitor our economic progress. In that spirit, we have focused on social priorities in our yearly recommendations to Member States as part of the European Semester.

The agreement on Posted Workers just last week will ensure that equal pay for equal work in the same place becomes a reality for all. And I expect further progress in the months to come on our proposals on fair and transparent working conditions and on work- life balance, as well as on our proposal for a new European Labour Authority which will improve information on rights and obligations across borders. I know that there are people in Europe who do not like this idea. We have a Banking Authority, why should we not have a Labour Authority? These things go together. Likewise, we are working to put social fairness first when it comes to our single market. Our companies and workers depend on a level- playing field.This is why we have used the tools at our disposal to make sure big companies pay their fair share of tax where the profits are made. And our proposal on corporate tax will also make sure there is a level playing field for all businesses and will help governments crack down on aggressive tax planning.

The second challenge that I see ahead of us is the need to complete our Economic and Monetary Union. And I see no better time to get it done.

Tommaso himself had no illusions of how difficult it is to progress when he said back in 2004: "The road towards the single currency looks like a chain reaction in which each step resolved a pre-existing contradiction and generated a new one". I believe that this is the time to overcome our contradictions. The future of the European Union is the future of the euro, and the future of the euro is the future of the European Union as a whole.

The good news is that we know what needs to be done.

The Five Presidents' Report in 2015 and the Reflection Paper on the Future of the Economic and Monetary Union in 2017 set out a way forward.

Although this is not often admitted, a lot has already been done, including by this Commission. Euro area governance has been reinforced through a greater focus within the European Semester, with important discussions every year on the specific priorities of the euro area.

The weaknesses of the banking sector, which were exposed during the crisis, are now being tackled slowly but surely. Our banks are stronger and the ratio of non-performing loans has been reduced by one third since 2014.

And I would also like to welcome the recent agreement between Finance Ministers, two weeks ago, on further risk-reduction measures in the banking sector, which is another important step towards the completion of the Banking Union. More has to be done, including the common deposit insurance scheme. This will not be introduced overnight; pre-conditions have to be fulfilled. But the Economic and Monetary Union will not be complete without this major instrument.

We are also making progress on a Capital Markets Union, to make sure that our businesses get easier and cheaper access to finance, as well as to reduce risks in the financial system.

And I am also proud that we stood up for Greece, which is now growing again and outperforming its fiscal targets. We still have work to do but I believe the successful conclusion of the Greek programme is within touching distance. This would be a remarkable achievement and testament to the efforts of the Greek people.

All in all, I can say that the architecture of the EMU is much more robust than ever before.

This is an important message to pass, but I can also say - without contradiction - that the 
job is not complete. We cannot be complacent about what remains to be done.

In December last year, the Commission presented a Roadmap and a series of proposals to complete the job. Last week, we presented two more proposals to make use of the European budget in order to strengthen the resilience of our economies: a Reform Support Programme - EUR 25 billion - and a European Investment Stabilisation Function EUR 30 billion. These two instruments can be developed over time.

These proposals are part of a coherent package for the future of the EU budget: they go hand in hand with all of our other instruments to boost jobs, growth, investment and convergence across Europe. These include the European Structural and Investment Funds; the future so-called InvestEU Fund, which will succeed our Investment Plan; the future Connecting Europe Facility or the future Research Programme - just to name a few.

But they are also part of a broader agenda to make our single currency the protecting and uniting force that it is conceived to be.

Completing the Economic and Monetary Union is more important than ever. Recent developments are a reminder of the need to make progress now.

I would like us to finally complete, as I said, the Banking Union and have the European Stability Mechanism play the role of a common backstop, as was already agreed in principle in 2013.

I would like the euro area to benefit from a strong budget line within the future European budget, as we propose it, to support their reforms and benefit from the strength of European solidarity.

I would like non-euro countries who wish to join the single currency to be able to prepare well and be supported on the way.

I would like decisions about our future to be taken collectively, in an inclusive and transparentmanner, with strong parliamentary scrutiny at all levels.

And I would like the euro area to speak more firmly and with one voice on the world scene. This is all the more important when you consider that within a few decades, no European country would qualify for the G7 on the basis of its economic size.

Discussions on all our proposals continue. I think we know and understand what is at stake. What we now need is the political will to match.

I will stop there because we know that we will not complete Europe's Economic and Monetary Union within the timeframe of this speech, and especially because you have many great speakers to listen to, including my friend Kristalina Georgieva whom I am delighted to see back in Brussels.

Throughout the day, you will discuss the future of our economy in a changing world around us. As you do so, my message to you is that we must never lose sight of what the Economic and Monetary Union stands for, and how it must continue to offer protection, prosperity and progress to all Europeans. This was the spirit and driving force of Tommaso.

I would like to finish with a small anecdote about him. As a young man Tommaso was asked a question by his teachers. They asked him whether he wanted to understand the world or whether he wanted to change the world. Tommaso replied that he wanted to do both. And this is why he chose economics.

And this is how we should all see economics: as a way to understand Europe and to make it an even better Union. This is how we should continue to honour Tommaso's legacy. 